\title{
Meningkatkan Pemahaman dan Aktivitas Belajar Siswa dalam Mengeja Penulisan Nama Tamu pada Slip Rak Kamar Mata Pelajaran Menyediakan Layanan Akomodasi Reception melalui Metode Pembelajaran Tutor Sebaya
}

\section{Ni Luh Sutiari*}

SMK Negeri 2 Singaraja, Singaraja, Indonesia

\section{A R T I C L E I N F O}

Article history:

Received 19 November 2018

Received in revised form 30 December 2018

Accepted 10 January 2019

Available online 20

February 2019

Kata Kunci:

aktivitas belajar siswa, metode pembelajaran tutor sebaya, pemahaman siswa

Keywords:

student learning activities, peer tutoring learning methods, student understanding.

\begin{abstract}
A B S T R A K
Tujuan dari diadakannya penelitian ini adalah untuk meningkatkan pemahaman dan aktivitas belajar siswa dalam mengeja penulisan nama tamu pada slip rak kamar mata pelajaran menyediakan layanan akomodasi reception melalui metode pembelajaran tutor sebaya pada siswa kelas XII P 2 semester II SMK Negeri 2 Singaraja tahun pelajaran 2017/2018. Penelitian ini adalah penelitian tindakan kelas dengan subjek siswa kelas XII P 2 semester II SMK Negeri 2 Singaraja tahun pelajaran 2017/2018. Sedangkan objeknya adalah pemahaman dan aktivitas belajar siswa. Data pemahaman siswa dikumpulkan dengan tes, sedangkan data aktivitas belajar siswa dikumpulkan dengan observasi. Analisis data yang digunakan pada penelitian ini menggunakan analisis data deskriptif. Berdasarkan penelitian yang telah dilakukan, didapatkan hasil bahwa pemahaman dan aktivitas belajar siswa dalam mengeja penulisan nama tamu pada slip rak kamar mata pelajaran menyediakan layanan akomodasi reception meningkat dengan menerapkan metode pembelajaran tutor sebaya pada siswa kelas XII P 2 Semester II SMK Negeri 2 Singaraja Tahun Pelajaran 2017/2018.
\end{abstract}

\section{A B S T R A C T}

The purpose of this research was to improve students' understanding and learning activities in spelling guest name writing on a shelf slip subject room providing accommodation reception services through peer tutoring learning methods in class XII P 2 semester II of SMK Negeri 2 Singaraja academic year 2017/2018. This research is a classroom action research with the subject of class XII P 2 semester II of SMK Negeri 2 Singaraja academic year 2017/2018. While the object is understanding and learning activities of students. Students' understanding data was collected by using tests, while students' learning activity data was collected by observation. Data analysis used in this study was descriptive data analysis. Based on the research that has been done, it is found that students' understanding and learning activities in spelling guests' name writing on shelf slips subject rooms providing reception accommodation services are increased by implementing peer tutoring learning methods to students of class XII P 2 Semester II SMK Negeri 2 Singaraja 2017/2018 Academic Year. 


\section{Pendahuluan}

Pendidikan merupakan usaha sadar dan terencana untuk mewujudkan suasana belajar dan proses pembelajaran atau pelatihan agar peserta didik secara aktif dapat mengembangkan potensi dirinya secara terus menerus sepanjang hidup yang diharapkan dapat memiliki kekuatan spiritual keagamaan, emosional, pengendalian diri, kepribadian, kecerdasan, akhlak mulia, serta keterampilan yang diperlukan dirinya dan masyarakat. Pemerintah selalu berusaha untuk meningkatkan kualitas pendidikan dengan berbagai cara seperti mengganti kurikulum, meningkatkan kualitas guru melalui penataran-penataran, memberi dana Bantuan Operasional Sekolah (BOS) dan sebagainya. Pemerintah mengatur kebijakan pendidikan sesuai dengan fungsi dan tujuan Pendidikan Nasional dalam UU RI No. 20 tahun 2003 SISDIKNAS Bab II Pasal 3,yaitu:

Pendidikan nasional berfungsi mengembangkan kemampuan dan membentuk watak serta peradaban bangsa yang bermartabat dalam rangka mencerdaskan kehidupan bangsa, bertujuan untuk berkembangnya potensi peserta didik agar menjadi manusia yang bertakwa kepada Tuhan YME, berakhlak mulia, sehat, berilmu, cakap, kreatif, mandiri dan menjadi warga negara yang demokratis serta bertanggug jawab.

Menghayati isi dari UU No. 20 tahun 2003 tersebut, peneliti berpendapat bahwa tugas seorang pendidik memang berat, sebab kemajuan suatu bangsa ditentukan oleh keberhasilan pendidikan dari bangsa itu sendiri. Jika seorang guru atau pendidik tidak berhasil mengembangkan potensi peserta didik maka negara itu tidak akan maju, sebaliknya jika guru atau pendidik berhasil mengembangkan potensi peserta didik, maka terciptalah manusia yang cerdas, terampil, dan berkualitas. Menurut Wina Sanjaya (2006:19), peran guru adalah: "Sebagai sumber belajar, fasilitator, pengelola, demonstrator, pembimbing, dan evaluator". Sebagai sumber belajar dan motivator guru harus mampu meningkatkan pemahanan dan membangkitkan motivasi siswa agar aktivitas proses pembelajaranberhasil dengan baik. Salah satu cara untuk meningkatkan pemahaman dan aktivitas siswa dalam proses pembelajaran adalah dengan mengganti model pembelajaran yang selama ini tidak diminati lagi oleh siswa, seperti pembelajaran yang dilakukan dengan ceramah dan tanya-jawab, model pembelajaran ini membuat siswa jenuh dan tidak kreatif. Suasana belajar mengajar yang diharapkan adalah menjadikan siswa sebagai subjek yang berupaya menggali sendiri, memecahkan sendiri masalah-masalah dari suatu konsep yang dipelajari, sedangkan guru lebih banyak bertindak sebagai motivator dan fasilitator. Situasi belajar yang diharapkan di sini adalah siswa yang lebih aktif.

Fenomena seperti diatas merupakan permasalahan yang perlu segera ditemukan alternatifalternatif pemecahannya. Salah satu upaya yang dapat dijadikan alternatif pemecahan masalah tersebut adalah dengan menerapkan pembelajaran yang meningkatkan pemahaman dan aktivitas belajar siswa melalui "metode tutor sebaya (peer tutoring)"pada slip rak kamar mata pelajaran Menyediakan Layanan Akomodasi Reception yang merupakan salah satu mata pelajaran produktif yang ada di SMK pariwisata, pada dasarnya Sekolah Menengah Kejuruan menciptakan peserta didik yang siap kerja, dalam upaya menyiapkan peserta didik yang handal dan memiliki kesiapan kerja, mereka dibekali dengan beberapa mata diklat yang dikelompokan menjadi 3 program yaitu program normatif, program adaptif, dan program produktif. Program produktif adalah kelompok mata diklat yang berfungsi membekali peserta didik agar memiliki kompetensi kerja sesuai Standar Kompetensi Kerja Nasional Indonesia (SKKNI). Oleh karena itu, dengan menggunakan metode pembelajaran tutor sebaya pada slip rak kamar mata pelajaran Menyediakan Layanan Akomodasi Reception, diharapkan peserta didik dapat lebih aktif dalam bertanya atau mengeluarkan pendapat, karena peserta didik tidak bertanya atau mengeluarkan pendapat langsung di dalam kelas, melainkan ke tutor dalam kelompoknya. Pada pembelajaran tutor sebaya ini, sebagian peserta didik diajak untuk menjadi tutor atau sumber belajar dan tempat bertanya bagi temannya, sehingga bimbingan secara individu kepada peserta didik akan menjadi lebih optimal.

Penelitian ini dikuatkan oleh penelitian sebelumnya yang dilakukan oleh Al Fatoni (2014) menyatakan berdasarkan hasil penelitian yang dilakukan dengan metode demonstrasi dapat meningkatkan pemahaman siswa dalam pembelajaran matematika dan mencapai KKM. Lukman Nulhakim (2016) menyatakan berdasarkan terdapat perbedaan kemampuan pemahaman matematika siswa antara siswa yang jarang diberi catatan perbaikan dengan yang tidak diberi catatan perbaikan. Afriyuni Yonanda (2017) Guru harus lebih mempersiapkan pembelajaran yang akan dilakukan melalui pemilihan materi yang sesuai dengan metode Mind Mapping dalam proses belajar mengajar pelajaran PKn, sehingga hasil pemahaman siswa akan meningkat dan memperoleh hasil yang maksimal sesuai dengan KKM yang diharapkan. Pramudia R. A (2016) berdasarkan hasil penelitian menunjukan bahwa tingkat pemahaman siswa kelas 5 tentang keselamatan dalam pembelajaran penjasorkes berada pada kategori "sangat kurang" sebesar 6,7\% (2 siswa), kategori "kurang" 23,3\% (7 siswa), kategori "sedang" 33,3\% (10 siswa), kategori "baik" 30,0\% (9 siswa), kategori "sangat baik" 6,7\% (2 siswa). Yani Nurhaeni (2016) Penggunaan 
pembelajaran kooperatif tipe jigsaw pada kompetensi meningkatkan pemahaman pelajaran fisika konsep listrik berhasil meningkatkan. Meningkatnya pemahaman siswa terhadap pelajaran fisika konsep listrik dapat di lihat dari meningkatnya hasil belajar siswa mlai dari siklus I sampai siklus IV.

Berdasarkan uraian tersebut penulis mencoba menerapkan salah satu metode pembelajaran, yaitu metode pembelajaran tutor sebaya untuk mengungkapkan apakah dengan model pembelajaran tutor sebaya dapat meningkatkan pemahaman dan aktivitas belajar siswa dalam mata pelajaran Menyediakan Layanan Akomodasi Reception. Dari latar belakang tersebut maka penulis dalam penelitian ini mengambil judul " Meningkatkan Pemahaman dan Aktivitas Belajar Siswa dalam Mengeja Penulisan Nama Tamu pada slip rak kamar mata Pelajaran Menyediakan Layanan Akomodasi Reception Melalui Metode Pembelajaran Tutor Sebaya Pada Siswa Kelas XII P 2 Semester II SMK Negeri 2 Singaraja Tahun Pelajaran 2017/2018.

\section{Metode}

Penelitian tindakan kelas ini dilaksanakan di SMK Negeri 2 Singaraja Lokasinya di Jalan Srikandi No. 9 Singaraja. Penelitian tindakan kelas ini kurang lebih dilaksanakan selama satu semester dimulai sejak minggu ketiga bulan Agustus sampai akhir bulan Nopember 2017.

Penelitian ini terfokus pada peserta didik kelas XII P 2 semester II tahun pelajaran 2017/2018. Hal ini dikarenakan peneliti merupakan guru Program Keahlian di Pariwisata yang mengampuh mata pelajaran Menyediakan Layanan Akomodasi Reception di kelas tersebut. Siswa kelas XII P 2SMK Negeri 2 Singarja berjumlah siswa 37 orang terdiri dari 25 orang siswa laki-laki dan 12 orang siswa perempuan.

Penelitian ini akan dilaksanakan dalam 2 siklus pembelajaran. Dimana masing-masing siklus pembelajaran terdiri dari empat tahap tindakan yaitu tahap perencanaan tindakan, pelaksanaan tindakan, observasi tindakan, dan tahap refleksi. Siklus ini dapat digambarkan sebagai berikut.

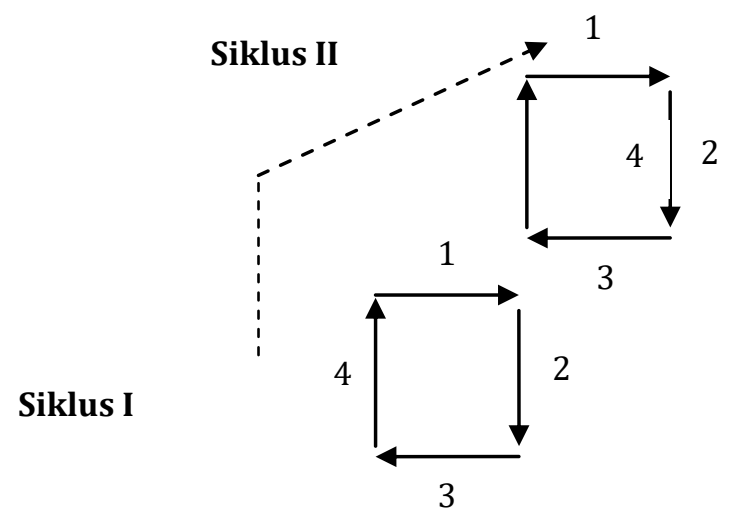

Gambar 1. Model PTK Dua Siklus (Agung, 2014: 141)

Keterangan:

1. Tahap perencanaan

2. Tahap tindakan

3. Tahap observasi/evaluasi

4. Tahap refleksi

a. Tahap Perencanaan (Planing)

Sebelum melaksanakan tindakan maka perlu tindakan persiapan. Kegiatan pada tahap ini adalah:

1) Menetapkan materi atau bahan ajar untuk 4 jam pelajaran @ 45 menit satu kali tatap muka

2) Penyusunan RPP dengan model pembelajaran yang direncanakan dalam PTK.

3) Menentukan teknik pelaksanaan model pembelajaran yang akan dilaksanakan yaitu dengan menggunakan model pembelajaran tutor sebaya.

4) Membuat instrument yang akan digunakan yaitu dengan menyusun lembar tes yang akan digunakan untuk mengetahui tingkat pemahaman siswa

5) Membuat instrument format observasi untuk melaksanakan pengamatan terhadap aktivitas belajar siswa pada kelompok besar

6) Menyiapkan angket untuk mengetahui tanggapan peserta didik terhadap model pembelajaran tutor sebaya yang diaplikasi pada Penelitian Tindakan Kelas 


\section{b. Pelaksanaan (Acting)}

Pelaksanaan yang dilakukan sesuai dengan judul Penelitian Tindakan Kelas yaitu menerapkan model pembelajaran tutor sebaya, dimana skrenario kerja tindakan meliputi:

1) Guru menyampaikan materi mengenai mengeja penulisan nama tamu

2) Beberapa peserta didik yang pandai (tutor) disuruh mempelajari materi lebih lanjut.

3) Guru memberi penjelasan umum tentang materi yang akan dibahas kepada peserta didik.

4) Kelas dibagi ke dalam kelompok besar, yaitu terdiri dari 8 orang peserta didik dan diusahakan kelompok yang dibentuk tersebut adalah kelompok yang heterogen.

5) Peserta didik yang pandai (para tutor sebaya) disebar ke setiap kelompok untuk memberi bantuannya.

6) Guru memonitoring dan membimbing terus kapan tutor maupun peserta didik yang lain membutuhkan pertolongan. Guru memonitoring tutor dengan berkunjung dan menanyakan kesulitan yang dihadapi setiap kelompok pada saat mereka diskusi maupun praktikum di kelas.

7) Jika ada masalah, tutor memberitahu peserta didik yang kurang paham dan jika ada masalah yang tidak dapat terpecahkan, tutor dan peserta didiknya meminta bantuan kepada guru.

8) Penguatan dan kesimpulan secara bersama-sama

9) Melakukan pengamatan dan observasi

10) Guru mengadakan evaluasi.

\section{c. Pengamatan (Observation)}

Pengamatan dilakukan untuk melihat situasi belajar mengajar, kegiatan pengamatan observasi ini dilakukan bersama-sama dengan kegiatan pelaksanaan tindakan diatas. Pengamatan yang dilakukan terdiri dari:

1) Pemahaman siswa dalam pengisian formulir pemesanan kamar

2) Aktivitas siswa dalam belajar pengisian formulir pemesanan kamar

3) Keberanian dalam menyampaikan pendapat

4) Kemampuan mengaplikasikan model pembelajaran tutor sebaya

\section{d. Refleksi (reflecting)}

Penelitian tindakan kelas ini dinilai berhasil apabila:

1) Meningkatnya pemahaman siswa dalam pengisian formulir pemesanan kamar

2) Meningkatnyaaktivitas siswa dalam belajar pengisian formulir pemesanan kamar yang dilihat setelah menggunakan model tutor sebaya

Refleksi dilakukan untuk mengamati pelaksanaan tindakan dan hasil penerapan metode tutor sebaya pada siklus I, maka setelah terlihat dari hasil observasi perlu adanya perbaikanperbaikan.Sehingga harus dilakukan siklus II dengan materi yang masih terkait dengan materi yang diberikan pada pelaksanaan di dalam siklus I yaitu mengenai pengisian formulir pemesanan kamar. Kegiatan pada siklus II pada dasarnya sama dengan kegiatan pada siklus I hanya saja perencanaan kegiatan mendasarkan pada hasil refleksi pada siklus I sehingga lebih mengarah pada perbaikan pada pelaksanaan siklus II.

Data aktivitas belajar siswa dikumpulkan dengan metode observasi. Observasi dilakukan dengan menggunakan lembar observasi aktivitas belajar siswa yang telah dipersiapkan. Sedangkan pemahaman belajar siswa dikumpulkan dengan menggunakan metode tes. Setelah data terkumpul, dilanjutkan dengan tahap analisis data. Analisis data yang digunakan pada penelitian ini adalah analisis deskriptif kuantitatif dan kualitatif.

\section{Hasil dan Pembahasan}

Tutor sebaya adalah sumber belajar selain guru, yaitu teman sebaya yang lebih pandai memberikan bantuan belajar kepada teman-teman sekelasnya di sekolah. Bantuan belajar oleh teman sebaya dapat menghilangkan kecanggungan. Bahasa teman sebaya lebih mudah dipahami. Dengan teman sebaya tidak ada rasa enggan, rendah diri, malu dan sebagainya untuk bertanya ataupun minta bantuan.

Berasarkan penelitian yang dilakukan dengan menerapkan metode tutor sebaya pada siklus I terlihat bahwa setelah pembagian kelompok dan pembagian tugas yang harus dikerjakan dalam kelompok besar, maka tampak siswa antusias dalam mengerjakan lembar kerja tersebut.

Pada pengerjaan tugas kelompok ini tidak terlihat adanya siswa yang bermain-main ataupun asyik mengerjakan pekerjaan yang lain, semuanya fokus dalam mengerjakan tugas masing-masing. Pada pelaksanaan kegiatan kerja kelompok tampak adanya siswa yang mengalami kesulitan dalam 
mengerjakan tugas dan untuk mengatasi kesulitannya tersebut mereka bertanya kepada ketua kelompok yang berperan sebagai tutor sebaya yang tugasnya membantu dan menjelaskan kesulitan yang dihadapi temannya. Namun ada pula siswa yang mengalami hambatan dalam mengerjakan tugas tersebut langsung bertanya kepada peneliti dan guru pengajar.

Aktivitas belajar siswa pada siklus I menunjukan bahwa: 1) ada 16 orang peserta didik (42\%) yang aktif mengajukan pertanyaan kepada tutornya, 2) ada 6 orang peserta didik (16\%) yang aktif menanggapi pertanyaan, 3) ada 5 orang peserta didik (13\%) yang aktif menyampaikan pendapat di depan teman sebayanya, 4) ada 31 orang peserta didik (81\%) yang aktif berdiskusi bersama teman satu kelompoknya, 5) ada 22 orang peserta didik (58\%) yang aktif memperhatikan materi yang disampaikan oleh tutornya, 6) ada 18 orang peserta didik (47\%) yang aktif menulis hal-hal yang penting pada materi yang telah disampaikan oleh tutor, dan 7) ada 37 orang peserta didik (100\%) yang aktif melakukan tugas-tugas sesuai dengan yang diminta oleh tutor atau gurunya.

Berdasarkan post tes yang telah dilakukan pada siklus II untuk mengukur pemahaman siswa didapatkan hasil bahwa siswa yang sudah tuntas dalam belajar baru mencapai 21 orang, yang memperoleh Predikat A berjumlah 2 orang dengan perolehan skor rerata3.85 - 4.00, yang memperoleh Aberjumlah 8 orang dengan perolehan skor rerata $3.51-3.84$, yang memperoleh pedikat B+ berjumlah 6 orang dengan perolehan skor rerata 3.18 - 3.50, yang memperoleh predikat B berjumlah 5 orang dengan perolehan skor rerata 2.85 - 3.17 siswa yang belum tuntas dalam belajar mencapai 16 oarang dengan perolehan skor reratadibawah 2.85 .

Pada siklus I terlihat bahwa dari 37 siswa yang ada, 16 siswa mendapatkan nilai kurang dari 72 ( 2.85) yang artinya nilainya masih di bawah KKM atau belum tuntas, sedangkan 21 siswa telah mendapatkan nilai diatas KKM atau telah tuntas.

Dengan melihat titik lemah yang terjadi pada sebagian kecil siswa berkenaan konsep dasar mengenai penulisan nama tamu. Maka perlu diadakan penjelasan yang mendasar pada anak-anak yang mengalami hambatan dengan memanfaatkan teman yang telah memahami konsep mengenai penulisan nama tamu tersebut untuk menjelaskannya. Mendata siswa yang memiliki kemampuan lebih dan mampu untuk menyampaikan materi yang dikuasainyakepada temannya.

Perlu dibentuk kelompok-kelompok kecil yang terdiri dari 4-5 orang siswa. Untuk berkolaborasi dalam belajar dan dipimpin oleh siswa yang memiliki kemampuan lebih dan mampu menyampaikan materi yang dikuasainya dan juga perlu dibuat suatu catatan-catatan dasar yang siswa sering salah dalam mengartikan seperti penulisan antara initial give name dan initial of middle name untuk ditindak lanjuti pada tindakan berikutnya.

Pada pelaksanaan siklus II ini tampak sekali bahwa siswa sangat antusias dalam mengerjakan tugas kelompok, semua siswa terlihat aktif bersama kelompoknya dalam menyelesaikan tugas yang diberikan oleh peneliti.

Aktivitas belajar siswa pada siklus II terlihat bahwa: 1) ada 31 orang peserta didik (81\%) yang aktif mengajukan pertanyaan kepada tutornya, 2) ada 20 orang peserta didik (53\%) yang aktif menanggapi pertanyaan, 3) ada 18 orang peserta didik (47\%) yang aktif menyampaikan pendapat di depan teman sebayanya, 4) ada 37 orang peserta didik (100\%) yang aktif berdiskusi bersama teman satu kelompoknya, 5) ada 29 orang peserta didik (81\%) yang aktif memperhatikan materi yang disampaikan oleh tutornya, 6) ada 31 orang peserta didik (81\%) yang aktif menulis hal-hal yang penting pada materi yang telah disampaikan oleh tutor, dan 7) ada 37 orang peserta didik (100\%) yang aktif melakukan tugastugas sesuai dengan yang diminta oleh tutor atau gurunya.

Selain aktivitas belajar yang meningkat pada siklus II, peningkatan juga terjadi pada pemahaman siswa. Pada siklus II siswa yang sudah tuntas dalam belajar meningkat menjadi $100 \%$ yaitu 37 orang, tidak ada siswa yang belum tuntas dalam belajar. Dengan perolehan skor predikat sebagai berikut, yang memperoleh predikat A berjumlah 4 orang dengan perolehan skor rerata $3.85-100$, yang memperoleh predikat A- berjumlah 10 orang dengan perolehan skor rerata $3.51-3.84$, yang memperoleh predikat $\mathrm{B}+$ berjumlah 8 orang dengan perolehan skor rerata3.18 - 3. 50. Yang memperoleh Predikat B berjumlah 15 orang dengan perolehan skor rerata 3.17 - 2.85.( rata - rata $86,08 \%$ )

Berdasarkan hasil evaluasi yang telah dilaksanakan dan dikoreksi didaptkan hasil yang sesuai dengan indikator pencapaian hasil yang diharapkan, karena dari 37 siswa kelas XII P 2 seluruhnya siswa mampu mendapatkan nilai sesuai KKM atau tuntas dan bahkan banyak siswa yang mencapai nilai di atas KKM, sehingga prosentasi siswa yang telah tuntas adalah $100 \%$

Dari hasil evaluasi yang telah diberikan ternyata seluruhnya siswa mampu mendapatkan nilai sesuai KKM atau tuntas dan bahkan banyak siswa yang mencapai nilai di atas KKM. Aktivitas belajar siswa secara keseluruhan telah sesuai dengan yang diharapkan oleh peneliti karena dalam mengerjakan soal latihan kelompok,siswa aktif berdiskusi bersama tutornya masing-masing. 


\section{Simpulan Dan Saran}

Berdasarkan hasil penelitian yang telah dilaksanakan, maka dapat disimpulkan bahwa aktivitas belajar siswa dalam mata pelajaran memproses Menyediakan Layanan Akomodasi Reception mengenai penulisan nama tamu menunjukkan kriteria sangat aktif yaitumengajukan pertanyaan kepada tutor sebanyak81\%, berdiskusi bersama teman satu kelompok sebanyak 100\%, memperhatikan materi yang disampaikan oleh tutor sebanyak $81 \%$,menulis hal-hal yang penting pada materi yang telah disampaikan oleh tutor sebanyak $81 \%$, melakukan tugas-tugas sesuai dengan yang diminta oleh tutor atau gurunya sebanyak $100 \%$.

Data hasil pemahaman belajar siswa menunjukkan bahwa pemahaman belajar siswa terhadap pembelajaran Menyediakan Layanan Akomodasi Reception mengenai penulisan nama tamu meningkat menjadi sangat baik.Hal ini dapat dilihat dari hasil post test yang telalah dilaksanakan di siklus I dan siklus II, siswa yang sudah tuntas dalam belajar dari 21 orang menjadi 37 orang, siswa yang sudah tuntas dalam belajar meningkat menjadi $100 \%$ yaitu sebanyak 37 orang. Dengan uraian sebagai berikut: peserta didik yang memperoleh predikat A dengan perolehan skor rerata $3.85-4.00$ yang asalnya berjumlah 2 orang meningkat menjadi 4 orang, peserta didik yang memperoleh Predikat A- dengan perolehan skor rerata 3.51 - 3.84 yang asalnya berjumlah 8 orang meningkat menjadi 10 orang, peserta didik yang memperoleh predikat B+ dengan perolehan skor rerata 3.18-3.50 yang asalnya berjumlah 6 orang meningkat menjadi 8 orang, peserta didik yang memperoleh predikat B dengan prolehan skor rerata $2.85-3.17$ yang asalnya 5 orang meningkat menjadi 15 orang dan tidak ada siswa yang belum tuntas dalam belajar. Nilai rata - rata yang diperoleh pada siklus I ( $72.03 \%$ ), siklus II $86.08 \%$. Jadi dengan menggunakan metode Tutor Sebaya (peer tutoring) nilai rata - rata siswa meningkat $14.05 \%$.

Berdasarkan simpulan di atas, dapat disampaikan beberapa saran yaitu: (1) Siswa kelas XII P 2 Semester II di SMK Negeri 2 Singaraja menunjukkan tanggapan yang baik setelah dilaksanakan metode Tutor Sebaya. Melihat hal tersebut peneliti menyarankan kepada guru untuk menggunakan metode tutor sebaya sebagai salah satu alternatif pembelajaran memproses Menyediakan Layanan Akomodasi Reception selanjutnya, (2) Jika menggunakan metode tutor sebaya maka dibutuhkan perencanaan yang baik dan pengelolaan waktu yang tepat, (3) Sebelum menerapkan metode tutor sebaya, terlebih dahulu guru harus mengetahui kemampuan siswa, sehingga tidak salah ketika akan memilih siswa untuk menjadi tutor.

\section{Daftar Rujukan}

Afriyuni Yonanda. (2017). Peningkatan Pemahaman Siswa Mata Pelajaran Pkn Tentang Sistem Pemerintahan Melalui Metode M2m (Mind Mapping) Kelas IV Mi Mambaul Ulum Tegalgondo Karangploso Malang. Jurnal Cakrawala Pendas. Vol. 3 No.1 edisi Januari.

Agung, A. A. Gede. 2014. Metodologi Penelitian Pendidikan. Singaraja: Undiksha.

Al Fatoni. (2014). Upaya dalam meningkatkan pemahaman siswa dalam mata pelajaran matematika dengan metode demonstrasi pada siswa kelas II MI Ma'arif Tanjung Anom.

Arikunto, Suharsimi. 2006. Prosedur Penelitian Suatu Pendekatan Praktik. Jakarta: Rineka Cipta.

Daryanto. 2008. Evaluasi Pendidikan. Jakarta. Rineka Cipta.

Fitria Tri Wardani. 2013. Penggunaan Media Gambar Untuk Meningkatkan Pemahaman Siswa Pada Mata Pelajaran Sosiologi. Jurnal Pendidikan dan Pembelajaran Untan. Vol 2, No 6.

Lukman Nulhakim. (2016). Pengaruh Frekuensi Pemberian Catatan Perbaikan Pada Latihan Matematika Terhadap Kemampuan Pemahaman Matematika. Jurnal SAP Vol. 1 No. 1 Edisi Agustus.

Pramudia R. A. (2016). Tingkat Pemahaman Siswa Kelas 5 Tentang Keselamatan dalam Pembelajaran Penjasorkes di Sd Negeri 5 Wates. Jurnal Tingkat Pemahaman Siswa UNY. Vol 2 No 1.

Sanjaya, Wina. 2009. Strategi Pemebelajaran Berorientasi Standar Proses Pendidikan. Jakarta: Kencana. 
Sardiman. 2007. Interaksi \& Motivasi Belajar Mengajar. Bandung: Raja Grafindo Persada.

Sudjana, Nana. 2010. Penilaian Hasil Proses Belajar Mengajar. Bandung: Remaja Rosdakarya.

Yani Nurhaeni. 2016. Meningkatkan Pemahaman Siswa Pada Konsep Listrik Melalui Pembelajaran Kooperatif Tipe Jigsaw Pada Siswa Kelas IX SMPN 43 Bandung. METODIK DIDAKTIK Jurnal Pendidikan Ke-SD-an UPI. Vol 10, No 2. 